\title{
Padang Restaurant Names in Surabaya: A Linguistic Anthropology
}

\author{
Dwi Windah Wulansari* \\ Universitas Airlangga, Indonesia \\ *Email: badrus2011@gmail.com
}

DOI https://doi.org/10.15294/lc.v15i1.25151

Submitted 29 June 2020. Revised 7 August 2020. Accepted 19 September 2020

\begin{abstract}
This study examines the naming of Padang restaurants in Surabaya. The results show that there are two strategies that business owners use in naming their Padang home businesses, namely by using convergence and divergence strategies. The choice of name related to the convergence strategy is the name of the owner; prayer and hope; place name; natural conditions; words that are allocated with food; words that reflect nationalism. Whereas the selection of names using the divergence strategy relates to the names of relatives, names of kings and respected people; place name; names related to togetherness and circumstances; and the name that is allocated with the taste of food. Semantically, the word used in naming Padang restaurants refers to a concept that describes the norms, values and outlook on life of the Minangkabau people.
\end{abstract}

Keywords: divergence; convergence; Minangkabau; restaurant

\section{INTRODUCTION}

When we hear the word Padang, the thing that comes to mind is of course Padang specialties such as Padang rice, Padang satay, or side dishes with coconut milk. Many Minangkabau people wander because of their belief that wandering is a place to prove one's self, with their success in wandering, then that person can be considered independent by the people in his village so that it becomes a prestige for themselves (Marta, 2014 , p. 34). Opening a Padang restaurant is one of the main efforts undertaken by overseas people from Minangkabau. The procedures for naming Padang restaurants reflect how ethnic attitudes toward the language they use in overseas land, so that it will prove that the Minangkabau people can adjust to overseas land. Because essentially giving a name is part of language activities. Language is the most important element of a culture (Koentjaraningrat, 1981, p. 57).

Each name has a reason why the owner gave it and also has its own meaning. There is a tendency for the naming of Padang restaurants to always refer to something related to kinship. According to Danesi and Perron (199, p. 151), name giving is extended across cultures to encompass inanimate referenta. When this is done, the objects somehow take on, as if by magic, as animate quality of their own. So the naming is based on the time when something was made, what is the main object, and also describes its own quality.

Allan (2001, p. 88) argues that many things can be given certain names, including building names. Allan added that the form of the name is determined by the particular (variety of) language being used, and its reference is fixed by the norms and conventions of that language. So a name will be very much determined by the particular type of language used by the name giver and also influenced by cultural custom values or certain agreements.

The name Padang is not only known as the capital of West Sumatra Province, but is also known as the name of a restaurant outside the city of Padang. Referring to Bove'e and Till's commemoration, the placement of the word "Padang" on the restaurant's nameplate is a symbol that the public has understood as a name that contains a message that is cheap, halal, and serves a variety of dishes so that there are many choices, and are easily accepted by anyone's tongue (Syarief, 2002). The interesting thing about Padang restaurants that we often encounter is the service that serves dishes very skillfully by carrying ten to fifteen plates of side dishes on both arms. The task of carrying side dishes on both arms seems difficult, but in that difficulty there are two great values that must be realized for the guest. First, the value of respect, which has the nuances of of- 
fering to respected guests, the second is the value of speed which proves that there is a concise way to serve food (Rahmat, 2017, p. 24).

In Surabaya itself there are many Padang restaurants that prove the number of Padang people who migrate to Surabaya. There are several Padang restaurants with a variety of different names. The names of Padang restaurants are not just mere names, but the names reflect the linguistic phenomena associated with place names, religion, names of relatives, and names of respected people.

Giving a name based on the name of the place to eat aims to provide information on the origin of the owner of the place where the food came from, so that it is more recognized by the wider community. There are places to eat that serve Minangkabau specialties in the form of restaurants, restaurants, ampera, lapau rice, kadai rice, and kapau rice.

Restaurants can be defined according to the food and drinks sold as well as the way they are served and the services provided to customers who come to enjoy a meal or just to relax but the prices incurred by visitors are also slightly more expensive. Meanwhile, a restaurant can be defined as a place that serves simple dishes and provides a place to enjoy a meal by setting a certain cheaper rate. Restaurants usually specialize in types of food such as Padang restaurants. Not much different from a restaurant, Ampera is also a place to eat Padang which means an abbreviation of the Mandate of the People Suffering. Ampera also serves dishes for the middle class or group at relatively cheap prices compared to other dining places.

Therefore, it is very interesting if the names of Padang restaurants are examined from anthropological linguistic studies. According to (Kridalaksana, 2011, p. 144), anthropological linguistics is a branch of linguistics that studies the variety and use of language in culture and language features related to social groups, religions, occupations, or kinship. While (Lauder \& Lauder, 2007: 231) explain that linguistic anthropology is one of the branches of linguistics that examines the relationship between language and culture, especially to observe how language is used in everyday interactions as a tool in social action.

Good interaction between individuals has been shown when the Minangkabau will open a business on an overseas land, so that it will prove that they can adjust to the overseas land. In interacting with individuals and in groups with other communities, language speakers can do two kinds of strategies, namely adaptation stra- tegies and identification strategies. Adaptation strategies can be called speech language theory. This theory focuses on accommodation and adaptation put forward by (Giles, 1991). This theory is derived from conversation accommodation theory. According to this theory, the speaker uses linguistic strategies to reach agreement or to show differences in his interactions with others. Agreeing is expressed by convergence. Meanwhile the divergence is done as a statement to reject (Gudykunst, 2002, p.187).

Convergence is often referred to as an interactive model that prioritizes change, exchange, comparison of behavior patterns that represent a society and produces communication that lasts all the time by establishing a focus, namely reciprocal relationships (Liliweri, 2001, p. 84). Convergence can occur positively when the communicator acts in a style similar to the communicant, and will be negative if it is done to humiliate, tease, or demean (West \& Turner, 2008, p. 225). Convergence is a strategy that someone does in adapting to others, and divergence is the absence of an effort from he speaker to show equality between them, or there is no concern if there is no accommodation with each other.

Divergence is communication away, because the speaker shows the difference to the other person (Littlejohn \& Foss, 2008, p. 153). Language divergence is done by the speaker if he wants to emphasize differences or widen social distance with the speaker. This convergence and divergence strategy is used to find out how language represents social distance in a society. Giles et al. (1991) provide some notes on the problem of convergence and divergence. Three of them are closely related to this research, namely: 1 . Speakers do not always need to do language convergence in speaking because not every speaker is able to do imitations; 2. There are different motivations for this divergence and convergence problem. Very necessary to maintain identity but meaningless if the speaker is hostile to the interlocutor; 3 . Convergence is not always seen as positive, and divergence is always seen as negative, unless the convergence or accommodation is intended to ridicule or denigrate certain variations of the language.

Research on the naming representation has been carried out by experts for example in (Aribowo, 2017) study entitled Linking Arabic, Islam, and Economy: Onomastics on Business Name of People of Arabic Descent in Indonesia which analyzes the use of Arabic in the store naming system in the Kliwon Market. The next research by (Sudaryanto, 2017) entitled Nama-Nama 
Geng Sekolah Di Yogyakarta: Kajian Linguistik Antropologi represents these names into several categories. Also the research done by Rahmat (2017) entitled "Nama-Nama Tempat Makan Khas Minangkabau Di Kota madya Bukittinggi"

In this paper, researchers will discuss how the Minangkabau people represented the naming of their Padang home business in the overseas land. In this case, we can see that they are trying to maintain the language of the community in the midst of the many mixing of other cultures in the era of globalization, bearing in mind that culinary businesses or traditional commodities are experiencing serious threats from culinary originating from abroad (Wijana, 2014, pp. 56-64) . Not only names are imported from other regions, but syntactic or grammatical structures will also be difficult to maintain. In this case the researchers took the object that is Padang restaurant in Surabaya area.

The background for naming a place to eat is based on the ideas generated by the respective owners of the restaurant. By knowing the background of the naming, then knowing the meaning contained in the name. This is also indicated by the naming background of the Minangkabau people, which is seen from the physical, habit, origin, parent's name, occupation, status, similarity and condition (Arni, Ermanto, \& Juita, 2017; Pramita, Ermanto, \& Juita, 2017).

\section{METHODS}

The method used in this research is descriptive qualitative method. In this study, researchers used data sources of Padang restaurant names in Surabaya. The first step in data collection is to photograph and record the names of Padang restaurants located in the Surabaya area. The researcher also interviewed several Padang restaurant owners who met the criteria of the researcher. The names are classified based on convergence and divergence strategies, then researchers represent these names based on proper names. In a deeper analysis, the groups will be analyzed using a semantic approach to find out the meaning contained in the naming of the Padang restaurant.

\section{RESULT AND DISCUSSION}

There are two types of strategies used by the Minangkabau ethnic group in naming their restaurant business, namely the divergence strategy and the convergence strategy. The definition of convergence communication means that va- rious information will produce and determine a relationship between two or more individuals, so that communication behavior must be studied on the basis of 'who is related to whom' (Suprapto, 2009 , p. 83). Convergence communication will be seen to be effective when the communication is attractive, predictable, and easy to understand (Littlejohn \& Foss, 2008, p. 153). Convergence can also occur negatively if it is done to shame, tease, or humiliate (West \& Turner, 2008, p. 225).

Meanwhile, divergence is communication away, because the speaker shows the difference to the other person (Littlejohn \& Foss, 2008, p. 153). Divergence cannot be mistaken as a way of disagreeing or not responding to the other person, divergence is also not the same as indifference, but they decide to negotiate or choose to distance themselves from communicating for various reasons (West \& Turner, 2008, p. 227) .

\section{Naming with Divergence Strategy}

To maintain Minangkabau culture and language, the names of Padang restaurants established in Surabaya need to be labeled with ethnic language elements, namely the Minangkabau language. If the divergence strategy is felt to be less prominent than the convergence strategy, it does not mean that the Minangkabau people cannot adapt to the culture or language in Surabaya which is their place of origin, but with reasons to maintain language or show their love for their homeland. This shows the existence of a positive divergence which is to maintain the culture and language of the hometown. Citing the opinion of West \& Turner (2008, p. 227), divergence is different from ignorance. They only decided to distance themselves so as not to socialize for various reasons. In connection with this, references used to name Padang restaurants can be classified into several types. The reference elements of the Minangkabau language relate to various things, namely: Name of relatives, kings, and people who are respected or respected; place name; aspects related to food; names related to togetherness and circumstances. For more details, these various references will be described as follows:

\section{Names of Relatives, Kings and Respected People}

The strong ties of relatives and friends in Malay culture have long been known. Therefore, this certainly affects the Minangkabau people in naming the Padang restaurant business. The name of a relative is usually used to respect the siblings or relatives. Examples of the naming are: Ampera Uni 2; Ajo Manih; Sabana Bundo Sati; 
RM. Pusako Bundo; Jaso Bundo; RM. Salero Bundo

The word "Uni" is a greeting word for the Minangkabau for 'older sister', while "ajo" is a greeting word for "older brother". While people who are respected usually use the word "bundo" which means 'mother'. Because the mother is very high degree by the Minangkabau people. In connection with words related to the names of relatives and respected people, the dominance of the greeting word "bundo" appears, which is a respectful call to 'mother'. This is not surprising, because for Minangkabau "bundo" is the most respected figure, because it is considered the most meritorious in one's life (Wijana, 2016, p. 199). Examples of the naming are: RM. Puri Ratu Minang; RM. Malin Intan; Ampera Salero Bagindo

In buying and selling activities there are pearls of wisdom that "the buyer is king". This term is also applied by the Minangkabau people in naming their restaurant business and is a form of respect for their buyers. The Minang people assume that the "king" must be placed in the most honored place (Wijana, 2016, p. 199). Here is an example of naming that is intended by the Minang in aligning its customers with the king. For example, such as the name "Puri Ratu Minang" which is considered as a restaurant owned by the king, "Malin Intan" is considered as a very valuable restaurant, while "Salero Bagindo" is a restaurant that serves delicious dishes like the tastes of the kings.

Salero Ambo. However a respect for oneself is also important. In terms of naming, there is a Padang restaurant in Surabaya that uses its own name to name its restaurant business. For example the word "ambo" which means 'me'.

\section{Place Name}

The Minangkabau people love their hometown very much. Therefore, there are several attachments between the names of their businesses and areas in West Sumatra. The names of Padang restaurants below reflect how closely the attachment can be described as follows: Ampera Palito Minang; PALAPA; RM. Padang Tercinto; RM. Kapau; RM. Ranah Minang; Minang Sabana.

The name of the place used is the name of a famous area in Padang. Like the word " $p a$ lapa" which stands for the name of the area in West Sumatra, namely 'Pariaman, Lubuk Alung, Padang'. The word "Minang" which shows that this restaurant belongs to "Minang people". And the word "Padang" shows the setting of the place, namely the cuisine of the people of Padang.

\section{Names Related to Togetherness and Circum- stances}

Ampera Manenggang. Togetherness and circumstances describe how Minangkabau people get along well. Reflected from the names used are the word "manenggang" which means "help" which illustrates that Minangkabau people like to help one another.

\section{Names Collocating with Food Taste}

Ampera Labuhan Raso. Minangkabau people also use the word collocated or its meaning adjacent to food, namely in the name of $\mathrm{Pa}$ dang restaurant "labuhan raso" which means "port of taste' related to the taste of food or 'raso' which is related to the 'sense of taste'.

\section{Naming with Convergence Strategy}

The convergence strategy is a reflection of how migrants from Minangkabau adapt to the environment, which in this study is Surabaya. The strategy is done by absorbing or using words from foreign languages or Indonesian that have been adapted into local languages. This study adapted Javanese language according to the research environment in Surabaya. In this study, there is a tendency of the Minangkabau ethnic group to change their mindset so that they can adapt to the environment where they live. In line with this thinking, Liliweri (2001: 84) in his book explained that the convergence strategy is often referred to as an interactive model that prioritizes changes, exchanges, comparisons and behavioral patterns that represent a society and produce communication that lasts all the time by establishing a focus that is the relationship reciprocal. This is evident from the names used to name the Padang restaurant business, which mostly use the convergence strategy. Naming related to the convergence strategy which has a word reference, namely the name of the owner; prayer and hope; place name; natural conditions; words that are related to food; words that reflect nationalism.

\section{Names of Owners}

The name of the business owner is also used by Minangkabau people to name their $\mathrm{Pa}$ dang restaurant business. This is proof that the Minangkabau people can adapt to the environment in Surabaya, because they do not use the Minangkabau language to name their Padang home. In interviews with restaurant owners, the selection of names related to the name of the owner was chosen so that consumers can easily re- 
member the name of the restaurant. These names are: Ampera Rydia; RM. Tiara; RM. Bareno; RM. Dicky Mulya.

\section{Hopes and Prayers}

From the researchers' observations, quite a lot of Padang restaurant names were later successful but did not use the Minangkabau language or overseas language in labeling his Padang restaurant. They prefer to take a name whose referents express simplicity, prayer and hope. In an interview with one of the Padang restaurant owners who chose to use a name related to hope and prayer, it was said that this was done to attract buyers to be interested in terms of a name that contains simplicity which reflects that the menu is simple and the price is cheap without reducing the perception about the good taste of the food despite the low price. The word "raya" itself is attached to the name of the restaurant has a meaning that is always successful, successful, great. The owner of the restaurant really supports the hope of his business to achieve a success that makes them prosperous. That is the prayer they put up in naming the Padang restaurant. There is an associative meaning contained in the name. The names of Padang restaurants are: Ampera Cahaya Minang; RM. Idola; Ampera Cemerlang; Ampera Hidup Baru; Surya Gemilang; RM. Sederhana; Muara Raya; Ampera Padang Raya; Ampera Murah Meriah; Sate Padang Sinar Gemilang; RM. Utama; Ampera Padang Sederhana; Padang Murah

\section{Place Name}

In this case, the choice of name is associated with the name of the place where the $\mathrm{Pa}$ dang restaurant was established. If in the divergence strategy the selection of names related to place names is based on well-known regional names in Minangkabau, in the convergence strategy the name of the place is dominated by the name of the area where the Padang house stands. According to the results of the interview, the selection of names is based so that buyers remember the name of the Padang restaurant, because usually someone remembers the names of the streets rather than the names of the Minangkabau language. This shows that the owner of Padang Restaurant can adapt to the overseas environment because the selection of names adjusts the name of the area where he is overseas. The names of Padang restaurants are: Ampera Bubutan; Simpang Raya; Ampera Kalibokor; RM. Rantau

\section{Natural Condition}

The name associated with natural conditions, the intention is to choose the name refers to the comfort of the Padang restaurant. For example in Padang restaurant which is called "Angin Santai", which translates to 'a relaxing wind' that reflects the natural state of calmness and relaxation: Angin Santai.

\section{Names Collocating with Food Taste}

This relates to the choice of name that reflects the pleasure of Padang cuisine which is very distinctive. The owner of the restaurant said that giving the name of this food so that the naming is different from the others, and so that buyers feel interested in the taste of food at the Padang house. The name of the Padang restaurant is: RM. Goyang Lidah.

\section{Words which Reflect Patriotism}

In this case, the naming reflects a sense of nationalism. This proves that the Minangkabau people do not discriminate between culture and language in terms of choosing names for their Padang home business. The names of Padang restaurants are: RM. Sari nusantara; Podomoro

The word "sari nusantara" can be interpreted as 'one nation', while the word "podomoro" is taken from the Javanese language which means 'all are equal'.

\section{CONCLUSION}

The large number of Padang restaurants established in Surabaya caused a tendency from the Minangkabau ethnic group to change their mindset so that they could adapt to the environment where they traveled. This is evident from the names used in naming the Padang restaurant business which mostly use the convergence strategy. The choice of name related to the convergence strategy is the name of the owner; prayer and hope; place name; natural conditions; words that are allocated with food; words that reflect nationalism. And the most prominent naming reference is prayer and hope. Several Padang restaurant business owners claimed that choosing the name in their business was also a prayer for the business. Other supporting referents are the name of the place and the name of the business owner, this referent is widely used by Padang restaurant owners because it is easily remembered by buyers.

The divergence or naming strategy using the Minangkabau language is not very much found in Surabaya, but the choice of names based on this divergence strategy cannot be mistaken 
as a Minangkabau person who does not want to adapt to foreign languages or culture, but rather to maintain language or show his love for the village page. The choice of name in the divergence strategy is related to the names of relatives, kings and respected people; place name; names related to togetherness and circumstances; and names related to food tastes. In the divergence strategy, naming related to the names of relatives, kings, and respected people is very dominant because it uses the name of a respected person who describes a person who is considered highly ranked, such as the word "bundo". Whereas names related to places describe some of the famous places in Padang or the birthplace of business owners.

\section{REFERENCES}

Allan, K. (2001). Natural language semantics. Blackwell Publisher.

Aribowo, E. K. (2017). Linking Arabic, Islam, and economy: Onomastics on bussiness name of people of Arab descent in Indonesia. KARSA: Journal of Social and Islamic Culture, 25( 2), 284- 306.

Hood, B. H. (2014). Semiotik \& dinamika sosial budaya. Komunitas Bambu

Giles, H., Coupland, N., \& Coupland, J. (1991). Accomodation theory: Communication, context and consequence. In H. Giles, J. Coupland, \& N. Coupland (Eds.), Contexts of accomodation: Development in applied linguistics. Cambridge University Press.

Gudykunst, W. B., \& Carmen M. L. (2002). Crosscultural communication theories, in W. B. Gudykunst \& B. Mody (Eds.). Handbook of international and intercultural communication. 2nd Ed. Sage Publications.

Koentjaraningrat. (1980). Pengembangan bahasa nasional sebagai unsur kebudayaan nasional. Politik bahasa nasional. Balai Pustaka.

Kridalaksana, H. (2011). Kamus linguistik (4 $4^{\text {th }}$ ed.).
Gramedia Pustaka Utama.

Lauder, A. F., \& Lauder, M. (2007). Berbagai kajian linguistik, in Kushartanti, et.al. (Eds). Pesona Bahasa: Langkah Awal Memahami Linguistik. Jakarta: PT Gramedia Pustaka Utama.

Liliweri, A. (2001). Gatra-gatra Komunikasi Antar Budaya. Pustaka Pelajar.

Littlejohn, S. W., \& Karen A. Foss (2008) Theories of human communication 9th edition. Thomson Wadsworth.

Marta, S. (2014). Konstruksi makna budaya merantau di kalangan mahaiswa perantau. Jurnal Kajian Komunikasi, 2(1), 27-43.

Mulyana, D. (2010). Ilmu Komunikasi: Suatu Pengantar. Remaja Rosdakarya.

Nusarini \& Marwati, L. S. (2014). Proses Penamaan Desa di Kabupaten Sleman. Literasi, 4(2), 207214.

Pramita, D. D., Ermanto, E., Novia, J. (2017). Sistem nama diri masyarakat etnis Minangkabau: Kajian nama panggilan pada masyarakat rantau Pasisia di Pariaman. Jurnal Bahasa dan Sastra, $4(2)$.

Sudaryanto. (2017). Nama-nama geng sekolah di Yogyakarta: Kajian linguistik antropologi. Kajian Linguistik dan Sastra, 2(1), 33-40.

Sugiyono (2012) Metode Penelitian Kuantitatif, Kualitatif, dan $R \& D$. Alfabeta

Suprapto, T. (2009) Pengantar teori dan managemen komunikasi. Medpress.

Syarief, S. (2002). Lima Cara Orang Padang Menuju Minang. Jakarta: Sekolah Entrepreneur Halsya Bintang Persada.

West, R., \& Turner, L.H. (2008). Pengantar teori komunikasi: Analisis dan aplikasi ( $3^{\text {rd }}$ ed.). Salemba $\mathrm{Hu}-$ manika.

Wijana, I. D. P. (2014). Bahasa, kekuasaan, dan resistensinya: Studi tentang nama-nama badan usaha di Daerah Istimewa Yogyakarta. Humaniora, 26(1), 56-64.

Wijana, I. D. P. (2016). Bahasa dan etnisitas: studi tentang nama-nama rumah makan Padang. Linguistik Indonesia, 34(2), 196-206. 